\title{
PENGARUH STRUKTUR AKTIVA, PROFITABILITAS DAN LIKUIDITAS TERHADAP STRUKTUR MODAL PADA PERUSAHAAN INDUSTRI PERTAMBANGAN YANG TERDAFTAR DI BURSA EFEK INDONESIA (BEI)
}

\author{
Andini Nurwulandari \\ Universitas Nasional, Jakarta \\ Email: andinmanajemen@gmail.com
}

\begin{abstract}
Abstrak
Penelitian ini bertujuan untuk mengetahui pengaruh struktur aktiva, profitabilitas dan likuiditas terhadap struktur modal pada perusahaan industri pertambangan yang terdaftar di Bursa Efek Indonesia (BEI). Penelitian ini menggunakan metode kuantitatif dengan sumber data berupa laporan keuangan perusahaan yang disusun dan dipublikasikan secara online oleh Bursa Efek Indonesia (BEI), serta studi perpustakaan. Analisis dilakukan dengan menggunakan analisis statistik deskriptif, regresi linier berganda dan uji korelasi bivariat. Hasil penelitian menunjukkan bahwa struktur aktiva berpengaruh positif terhadap struktur modal, artinya semakin kompleks struktur aset maka semakin rumit struktur modal. Sebaliknya, variabel profitabilitas, dan likuiditas tidak berpengaruh terhadap struktur modal.
\end{abstract}

Kata Kunci: Struktur Aktiva, Profitabilitas, Likuiditas, Struktur Modal, BEI.

\begin{abstract}
This study aims to determine the effect of asset structure, profitability and liquidity on the capital structure of mining industry companies listed on the Indonesia Stock Exchange (IDX). This study uses quantitative methods with data sources in the form of company financial statements compiled and published online by the Indonesia Stock Exchange (IDX), and library studies. The analysis was performed using descriptive statistical analysis, multiple linear regression and bivariate correlation test. The results showed that the asset structure had a positive effect on the capital structure, meaning that the more complex the asset structure, the more complex the capital structure was. On the other hand, profitability and liquidity variables have no effect on capital structure.
\end{abstract}

Keywords: Asset Structure, Profitability, Liquidity, Capital Structure, IDX.

\section{A. PENDAHULUAN}

Struktur aktiva adalah rasio berbagai jenis sekuritas yang diperoleh oleh perusahaan sebagai keuangan jangka panjang (Apriyanto, Yunita \& Iradianti, 2017). Ini melibatkan dua keputusan utama yaitu; jenis saham yang akan diterbitkan antara lain saham ekuitas, saham preferen dan pinjaman jangka panjang serta rasio relatif dari efek yang ditentukan melalui proses capital gearing (Arsyad, 2015). Dasar ini menyebabkan perusahaan dibagi menjadi perusahaan yang sangat diarahkan dan perusahaan yang diarahkan rendah. Sementara 
perusahaan dengan rasio tinggi memiliki kapitalisasi ekuitas yang kecil, perusahaan dengan rasio roda gigi rendah memiliki proporsi kapitalisasi ekuitas yang tinggi (Christa \& Pratomo, 2013).

Struktur aktiva suatu perusahaan harus seoptimal mungkin agar dapat merealisasikan manfaat yang sebesar-besarnya bagi suatu perusahaan (Kosasih, 2017). Modal aktiva merupakan sumber pembiayaan berbiaya rendah di Indonesia karena bunga hutang merupakan biaya yang diperbolehkan untuk keperluan perpajakan (Kustina, Anwar \& Mawar, 2018). Perusahaan dapat memperoleh modal hutang dan membayar kembali sesuai dengan arus kas yang diharapkan, memberikan perusahaan fleksibilitas yang lebih besar untuk merencanakan dan mengontrol struktur modalnya (Mawaddah \& Nurwulandari, 2019). Ekuitas lebih mahal karena sifatnya yang permanen. Perusahaan terlibat dalam pembiayaan pinjaman untuk memperluas skala operasi mereka (Melati \& Nurwulandari, 2019).

Rasio likuiditas digunakan dalam mendukung pengelolaan likuiditas di dalam setiap organisasi berupa rasio lancar dan rasio cepat yang bertujuan sangat berpengaruh terhadap profitabilitas organisasi (Mitroglou, 2019). Dengan demikian bisnis memiliki aset likuid yang memadai (kas perusahaan) untuk memenuhi program pembayaran dengan membandingkan kas dan hampir tunai di antara kewajiban pembayaran. Aset kas terdiri dari piutang dari pelanggan dan persediaan barang lengkap dan bahan yang belum diolah. Arus kas operasi yang dihasilkan oleh aset akan mempengaruhi likuiditas perusahaan yang berkelanjutan. Kewajiban kompensasi termasuk iuran kepada pemasok, biaya operasional dan keuangan yang harus dibayar segera dan angsuran jatuh tempo berdasarkan hutang jangka panjang (Noer, Saribanon \& Nurwulandari, 2017).

Signifikansi ditentukan berdasarkan parameter berikut: aspek terapan dan kontribusi teoritis dari tubuh pengetahuan (Rahim, Zahari \& Shariff, 2016). Model yang dikembangkan untuk penelitian ini dapat digunakan secara efektif untuk meningkatkan likuiditas demi profitabilitas perusahaan (Nur, Effendy, Djaenuri \& Lukman, 2019). Penelitian ini mencakup pengembangan model yang menjelaskan hubungan antara likuiditas dan profitabilitas merupakan kontribusi asli bagi tubuh pengetahuan (Robiyanto, 2017). Dengan memperhatikan hal-hal di atas, penelitian tersebut tampaknya sangat signifikan (Soedarmono, 2018).

Likuiditas merupakan faktor penting selama krisis keuangan (Subhi \& Fithriyah, 2014). Karena ketidakpastian menyebabkan sumber pendanaan menguap, banyak perusahaan dengan cepat menemukan diri mereka kekurangan uang tunai untuk menutupi kewajiban mereka saat jatuh tempo (Suharsono \& Wibisono, 2016). Dalam kasus yang ekstrim, perusahaan di beberapa negara gagal atau dipaksa melakukan merger (Suparmun, 2012). Akibatnya, untuk kepentingan stabilitas keuangan yang lebih luas, sejumlah besar likuiditas disediakan oleh otoritas di banyak negara, termasuk Indonesia dan Malasya (Zuhri \& Endri, 2017).

Dengan demikian, para pembuat kebijakan telah menyarankan bahwa perusahaan harus memiliki aset yang lebih likuid daripada di masa lalu, untuk membantu mengasuransikan diri terhadap potensi kesulitan likuiditas atau pendanaan. Hal ini menyebabkan keinginan internasional untuk mengukur dan standar umum untuk risiko 
likuiditas, yang berpuncak pada pekerjaan berkelanjutan oleh Komite Basel untuk Pengawasan Perperusahaanan.

Karena aset likuid seperti uang tunai dan sekuritas pemerintah umumnya memiliki pengembalian yang relatif rendah, memegangnya membeperusahaanan biaya peluang pada perusahaan. Dengan tidak adanya regulasi, adalah wajar untuk mengharapkan perusahaan akan memegang aset likuid sejauh mereka membantu memaksimalkan profitabilitas perusahaan. Selain itu, pembuat kebijakan memiliki opsi untuk meminta kepemilikan aset likuid yang lebih besar, tujuan dari makalah ini bukanlah untuk menetapkan tingkat ideal dari kepemilikan alat likuid, melainkan untuk membantu membedakan secara empiris, apakah kepemilikan perusahaan atas alat likuid memiliki pengaruh yang signifikan terhadap profitabilitas mereka. Jika demikian, informasi empiris dasar tersebut sangat penting untuk kalibrasi yang tepat dalam konteks regulasi likuiditas domestik dan internasional. Meskipun regulasi dapat membuat sistem keuangan lebih tahan terhadap guncangan likuiditas, kalibrasi harus mengenali biaya yang terkait dengan efisiensi perantara keuangan karena hal ini dapat mengakibatkan biaya pinjaman yang lebih tinggi untuk agen lain dalam sistem.

Arus kas operasi yang dihasilkan oleh aset akan mempengaruhi likuiditas perusahaan yang berkelanjutan. Bukan hanya karena nilai likuidasi. Perusahaan dengan aset lancar yang lebih sedikit akan mengalami masalah dalam melanjutkan operasinya sedangkan jika aset lancar terlalu banyak, hal tersebut menunjukkan pengembalian investasi tidak dalam kondisi sempurna. Karena tingkat kas yang optimal dipengaruhi oleh faktor-faktor di luar konsep pencegahan perbendaharaan, perusahaan harus berpikir luas dan mengambil keputusan operasional yang serius tentang bagaimana peluang keuntungan yang tersedia dalam proses arus kas. Hal ini pada gilirannya dapat mempengaruhi operasi bisnis dan profitabilitas perusahaan. Prinsip Likuiditas versus Profitabilitas: Ada trade-off antara likuiditas dan profitabilitas; mendapatkan lebih dari satu biasanya berarti melepaskan sebagian dari yang lain. Dilema dalam pengelolaan likuiditas adalah tercapainya trade-off yang diinginkan antara likuiditas dan profitabilitas. Penelitian ini berupaya menyelidiki pengaruh struktur aktiva, profitabilitas dan likuiditas terhadap struktur modal pada perusahaan industri pertambangan yang terdaftar di Bursa Efek Indonesia (BEI).

\section{B. METODE}

Penelitian ini menggunakan teknik kuantitatif dengan interpretasi deskriptif. Sumber data meliputi laporan data keuangan milik perusahaan yang dikumpulkan dari BEI dan dipublikasikan secara online, serta melakukan analisis perpustakaan dengan mengumpulkan data dari penulisan buku dan jurnal terkait. Jenis data yang digunakan dalam penelitian yaitu data sekunder dari tahun 2014 hingga 2018 yang dikumpulkan melalui proses purposive sampling. Analisis Deskriptif Statistik, Analisis Regresi Linier Berganda, dan Uji Korelasi Bivariat digunakan dalam analisis studi.

\section{HASIL DAN PEMBAHASAN}

\section{Struktur Aktiva}

Tabel berikut merangkum hasil estimasi dan pertumbuhan struktur aset pada perusahaan sampel penelitian: 
ARTIKEL

Tabel 1 Hasil Perhitungan dan Perkembangan Struktur Aktiva Perusahaan

\begin{tabular}{|c|c|c|c|c|c|c|c|c|c|}
\hline \multirow{2}{*}{$\begin{array}{c}\text { Kode } \\
\text { Perusahaan }\end{array}$} & \multicolumn{5}{|c|}{ Tahun } & \multirow{2}{*}{$\begin{array}{c}\% \text { Naik } \\
\text { (Turun) } \\
2014- \\
2015 \\
\end{array}$} & \multirow{2}{*}{$\begin{array}{c}\% \text { Naik } \\
\text { (Turun) } \\
2015- \\
2016 \\
\end{array}$} & \multirow{2}{*}{$\begin{array}{c}\text { \% Naik } \\
\text { (Turun) } \\
2016- \\
2017\end{array}$} & \multirow{2}{*}{$\begin{array}{c}\% \text { Naik } \\
\text { (Turun) } \\
2017- \\
2018 \\
\end{array}$} \\
\hline & 2014 & 2015 & 2016 & 2017 & 2018 & & & & \\
\hline ANTM & 4.208 & 9.214 & 8.090 & 4.200 & 8.808 & 4.204 & 1.8680 & $(6.97)$ & $(4.493)$ \\
\hline PTBA & 8.299 & 7.290 & 5.578 & 1.568 & 1.891 & $(3.799)$ & $(2.683)$ & 6.97 & $(1.434)$ \\
\hline BUMI & 4.697 & 7.549 & 6.388 & 2.684 & 3.374 & $(8.277)$ & $(2.151)$ & $(4.705)$ & 1.0 .7 \\
\hline СТTH & 9.598 & 4.371 & 6.282 & 2.084 & 1.811 & $(6.336)$ & 1.921 & $(5.175)$ & $(1.384)$ \\
\hline ELSA & 9.732 & 7.576 & 2.659 & 5.943 & 3.287 & $(3.256)$ & $(5.927)$ & 4.275 & $(3.737)$ \\
\hline ATPK & 6.548 & 7.454 & 7.424 & 1.782 & 1.250 & 1.996 & $(1.03)$ & $(6.643)$ & (1.623) \\
\hline ENRG & 1.080 & 1.024 & 1.009 & 1.048 & 1.050 & $(1.066)$ & $(1.004)$ & 1.04 & 1.003 \\
\hline MITI & 8.861 & 5.580 & 5.857 & 9.630 & 4.361 & $(6.228)$ & 1.287 & $(7.237)$ & $(6.268)$ \\
\hline RUIS & 1.105 & 9.588 & 8.378 & 5.824 & 4.363 & 9.494 & 1.792 & $(5.566)$ & 2.538 \\
\hline KKGI & 3.702 & 1.048 & 9.683 & 22.180 & 8.244 & $(3.043)$ & $(2.375)$ & 3.498 & $(2.937)$ \\
\hline
\end{tabular}

Sumber: data diolah

Seperti terlihat pada Tabel 1, hasil estimasi dan pembuatan struktur aset dari sepuluh perusahaan di BEI mengalami fluktuasi setiap tahun. Dari tahun 2014 hingga 2018 mengalami penurunan sebagai akibat dari penurunan laba dan aset perusahaan sehingga menurunkan persentase struktur aset masing-masing perusahaan.

Table 2 Descriptive Statistics Struktur Aktiva Perusahaan

\begin{tabular}{|c|c|c|c|c|c|}
\hline & N & Min. & Max. & Mean & Std. Deviation \\
\hline 2014 & 10 & .080 & 237.890 & 42.68280 & 69.688210 \\
2015 & 10 & .021 & 165.190 & 35.94430 & 47.221520 \\
2016 & 10 & .009 & 36.270 & 20.52770 & 13.148782 \\
2017 & 10 & .040 & 117.740 & 29.19080 & 33.463636 \\
2018 & 10 & .050 & 123.740 & 29.23590 & 36.465269 \\
Valid N & 10 & & & & \\
\hline
\end{tabular}

Sumber: Data diolah

Rata-rata struktur aset perusahaan pertambangan terbesar di Indonesia adalah 42,68 pada tahun 2014. Dan nilai standar deviasi terendah pada 2015 dengan angka 21,52 sedangkan nilai standar deviasi maksimal pada 2014 sebesar 69,68. Hal ini menunjukkan bahwa pada tahun 2014, struktur aset perusahaan sampel paling bervariasi, berkisar antara 237,87 hingga 0,08. Kondisi ini berarti aset dasar perusahaan cukup stabil untuk dianggap stabil, selama rata-rata kenaikan tahunan tidak melebihi level tertentu.

\section{Profitabilitas}

Profitabilitas didefinisikan sebagai hubungan antara laba bersih dan total aset. Tabel berikut merangkum hasil perhitungan dan profitabilitas pada perusahaan industri pertambangan di BEI dari 2014 hingga 2018: 
ARTIKEL

Tabel 3 Profitabilitas Perusahaan Industri Pertambangan

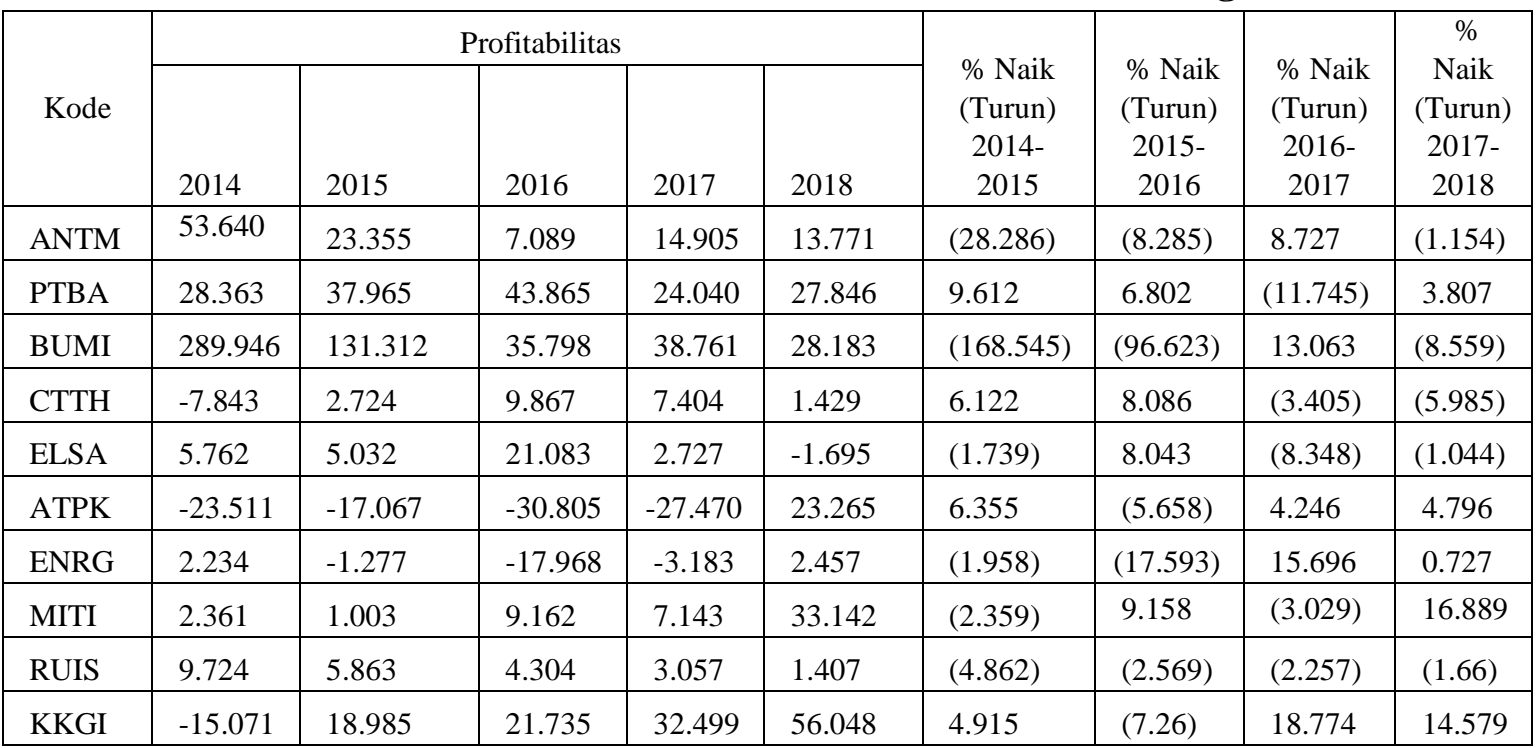

Sumber: data diolah

Dari tabel tersebut, dapat diketahui bahwa hasil pengukuran serta profitabilitas sepuluh perusahaan fluktuasi setiap tahunnya. Dari 2014 hingga 2018, profitabilitas masingmasing perusahaan meningkat dan menurun. PT. Radiant Utama Interinsco merupakan salah satu perusahaan yang mengalami keterpurukan dari tahun 2014 hingga 2018 akibat penurunan laba perusahaan.

Tabel 4 Descriptive Statistics Profitabilitas Perusahaan

\begin{tabular}{|c|c|c|c|c|c|}
\hline & $\mathrm{N}$ & Min & Max & Mean & Std. Deviation \\
\hline 2014 & 10 & -21.422 & 278.846 & 31.66820 & 89.049923 \\
2015 & 10 & -16.067 & 122.311 & 17.47790 & 38.357880 \\
2016 & 10 & -20.805 & 34.765 & 7.12390 & 16.536733 \\
2017 & 10 & -17.560 & 37.851 & 10.27700 & 16.590806 \\
2018 & 10 & -.0 .785 & 46.048 & 16.17300 & 15.9936723 \\
Valid N & 10 & & & & \\
\hline
\end{tabular}

Sumber: Data diolah

Berdasarkan hasil Tabel 4, rata-rata laba 31,66 perusahaan pertambangan terbesar di Indonesia tercatat pada tahun 2014. Terendah pada tahun 2015 sebesar 7,12, sedangkan deviasi standar tertinggi pada tahun 2014 terjadi dengan default 89,04. Hal ini menunjukkan bahwa profitabilitas perusahaan sampel paling berbeda dengan nilai 278,84 tinggi dan nilai 0,78 yang lebih rendah. Keadaan ini menunjukkan bahwa kondisi profitabilitas usaha sampel berfluktuasi antara tahun 2014 dan 2018, setiap sektor pertambangan di Indonesia mengalami fluktuasi pendapatan, sehingga hal ini mempengaruhi value profitabilitasnya. 


\section{Likuiditas}

Likuiditas mengacu pada kapasitas bisnis untuk memenuhi kewajiban langsungnya. Likuiditas dapat di kalkulasi dengan menggunakan current ratio. Tabel berikut merangkum hasil estimasi likuiditas pada perusahaan yang menjadi objek penelitian:

Tabel 5 Likuiditas Perusahaan Industri Pertambangan

\begin{tabular}{|c|c|c|c|c|c|c|c|c|c|}
\hline \multirow{2}{*}{ Kode } & \multicolumn{5}{|c|}{ Likuiditas } & \multirow{2}{*}{$\begin{array}{c}\text { \% Naik } \\
\text { (Turun) } \\
2014- \\
2015\end{array}$} & \multirow{2}{*}{$\begin{array}{c}\text { \% Naik } \\
\text { (Turun) } \\
2015- \\
2016\end{array}$} & \multirow{2}{*}{$\begin{array}{c}\% \text { Naik } \\
\text { (Turun) } \\
2016-2017\end{array}$} & \multirow{2}{*}{$\begin{array}{c}\% \text { Naik } \\
\text { (Turun) } \\
2017-2018 \\
\end{array}$} \\
\hline & 2014 & 2015 & 2016 & 2017 & 2018 & & & & \\
\hline ANTM & 457.420 & 820.395 & 737.407 & 397.705 & 1074.242 & 372.995 & $(32.986)$ & $(349.803)$ & 686.638 \\
\hline PTBA & 453.309 & 375.835 & 481.336 & 589.153 & 473.248 & (78.484) & 135.481 & 88.837 & (125.816) \\
\hline BUMI & 15.185 & 127.309 & 97.945 & 198.753 & 120.247 & 113.044 & $(21.218)$ & 22.771 & $(79.408)$ \\
\hline CTTH & 79.077 & 86.363 & 98.905 & 123.269 & 121.877 & 7.287 & 13.552 & 16.275 & $(2.303)$ \\
\hline ELSA & 109.331 & 149.205 & 155.386 & 171.870 & 134.599 & 31.884 & 15.178 & 9.586 & $(47.383)$ \\
\hline ATPK & 717.191 & 396.877 & 290.548 & 244.304 & 156.121 & $(330.316)$ & (107.094) & (47.568) & (89.094) \\
\hline ENRG & 63.278 & 192.086 & 49.001 & 62.288 & 64.358 & 129.807 & $(144.086)$ & 14.288 & 2.083 \\
\hline MITI & 67.646 & 73.880 & 129.148 & 136.769 & 169.154 & 6.126 & 47.378 & 8.622 & 34.383 \\
\hline RIUS & 297.678 & 178.476 & 227.399 & 159.544 & 117.685 & (87.214) & 19.933 & (77.864) & $(42.838)$ \\
\hline KKGI & 227.263 & 246.987 & 215.686 & 243.990 & 292.398 & 25.736 & $(32.313)$ & 29.285 & 49.427 \\
\hline
\end{tabular}

Sumber: data diolah

Dari tabel 5, diketahui bahwa hasil kalkukasi dan pertumbuhan likuiditas sepuluh perusahaan mengalami fluktuasi setiap tahunnya. Berdasarkan data pertumbuhan sejak 2014 hingga 2018, PT Mitra Investindo mengalami peningkatan selama lima tahun terakhir sehingga memungkinkan perseroan memenuhi kewajiban jangka pendek.

\section{Tabel 6 Desriptive Statistics Struktur Modal Perusahaan}

Descriptive Statistics

\begin{tabular}{|c|c|c|c|c|c|}
\hline & N & Min. & Max. & Mean & Std. Deviation \\
\hline 2014 & 10 & 10.916 & 533.891 & 162.84720 & 159.392950 \\
2015 & 10 & 20.996 & 551.491 & 183.96240 & 167.890800 \\
2016 & 10 & 21.552 & 487.956 & 184.30620 & 161.401835 \\
2017 & 10 & 27.598 & 435.492 & 138.66330 & 122.703291 \\
2018 & 10 & 40.832 & 527.425 & 178.86470 & 157.882781 \\
Valid N & 10 & & & & \\
\hline
\end{tabular}

Sumber: Data diolah

Temuan pada Tabel 6 menunjukkan bahwa rata-rata struktur permodalan untuk perusahaan pertambangan terbesar di Indonesia adalah 184,30 pada tahun 2016 dan yang terendah adalah 138,66 pada tahun 2017, sedangkan standar deviasi terbesar adalah 167,89 pada tahun 2015. Hal tersebut menunjukkan bahwa sampel struktur permodalan perusahaan paling bervariasi pada tahun 2015 yaitu 551,49 dan 20,99 dengan nilai terendah. Keadaan ini menunjukkan bahwa pada sampel perusahaan Indonesia kondisi struktur modal usaha 
berfluktuasi yang menyebabkan naik atau turunnya rasio modal sendiri terhadap hutang jangka panjang.

\section{Korelasi Bivariat}

Untuk mengevaluasi hubungan linier antara satu variabel dan variabel lainnya, digunakan analisis korelasi Pearson (Correlate Bivariaate). Data yang digunakan adalah rasio atau interval. Nilai korelasi (r) adalah 0 banding 1 .

Tabel 7 Analisis Korelasi Pearson dan Spearman

\begin{tabular}{|c|c|c|}
\hline \multirow[b]{2}{*}{ Variabel } & \multicolumn{2}{|c|}{ Struktur Modal } \\
\hline & $\begin{array}{l}\text { Korelasi } \\
\text { Pearson }\end{array}$ & $\begin{array}{c}\text { Korelasi } \\
\text { Spearman }\end{array}$ \\
\hline Struktur Aktiva & $\begin{array}{c}0,550 * * \\
0.001\end{array}$ & $\begin{array}{l}0.123 \\
0.140 \\
\end{array}$ \\
\hline Profitabilitas & $\begin{array}{l}0.173 \\
0.063 \\
\end{array}$ & $\begin{array}{l}(0.039) \\
0.0487 \\
\end{array}$ \\
\hline Likuiditas & $\begin{array}{c}(0.308)^{*} \\
0.029\end{array}$ & $\begin{array}{c}(0.709)^{* *} \\
0.001\end{array}$ \\
\hline Dummy & $\begin{array}{l}0.055 \\
0.334\end{array}$ & $\begin{array}{c}0.095 \\
0.18\end{array}$ \\
\hline
\end{tabular}

Sumber: Data diolah

Data menunjukkan jumlah yang cukup besar sebesar 0,001 dan 0,019 untuk variabel korelasi Pearson dari struktur aset dan likuiditas. Uji korelasi Pearson memperlihatkan variabel ini penting memiliki arah sama dengan likuiditas. Uji korelasi Spearman memperlihatkan bahwa variabel Proftabilitas penting, tetapi bertentangan dengan hipotesis, adalah likuiditas pada level yang relevan sebesar 0,001. Sedangkan struktur aset dan profitabilitas tidak menjadi masalah.

\section{Regresi Linier Berganda}

Pengujian regresi berganda dilakukan untuk menganalisis pengaruh variabel independen terhadap variabel dependen. Variabel independen adalah struktur aset (STA), struktur modal adalah profitabilitas (PROF), likuiditas (LIK) dan struktur modal (LEV).

Tabel 8 Regresi Linier Berganda

\begin{tabular}{crlrr}
\hline \multicolumn{1}{c}{ Variable } & Coefficient & Std. Error & t-Statistic & Prob. \\
\hline C & -41.29286 & 64.88993 & -0.635717 & 0.5281 \\
STA & 0.883707 & 0.313445 & 3.172544 & 0.0030 \\
PROF & -0.479004 & 0.390778 & -0.967684 & 0.3368 \\
LIK & -0.040199 & 0.025709 & -1.569404 & 0.1300 \\
R-squared & 0.293936 & Mean dependent var & & 162.5058 \\
Adjusted R-squared & 0.247732 & S.D. dependent var & & 159.6512 \\
S.E. of regression & 139.3996 & Akaike info criterion & & 12.88984 \\
Sum squared resid & 1807925. & Schwarz criterion & & 12.96330 \\
Log likelihood & -631.8819 & F-statistic & 6.143088 \\
Durbin-Watson stat & 2.186862 & Prob. (F-statistic) & & 0.000029 \\
\hline
\end{tabular}

Sumber: data diolah 
Tabel 8 menunjukkan bahwa nilai penting adalah struktur aset 0,003 berdasarkan temuan dari Persamaan Regresi dalam model analisis Variabel Independen. Sedangkan untuk variabel produktivitas, profitabilitas dan likuiditas, terdapat nilai yang dapat diabaikan. Hasil ini menjelaskan perhitungan regresi berganda dari variabel independen memiliki pengaruh cukup signifikan terhadap struktur sumber daya yaitu profitabilitas, struktur aktiva dan likuiitas pada $\alpha=5$ persen. Tiga variabel independen yang tidak berpengaruh besar pada valuasi perusahaan adalah produktivitas, laba, dan likuiditas.

Berdasarkan temuan investigasi, dapat disimpulkan bahwa perhitungan regresi multifaset berpengaruh penting dan positif terhadap struktur permodalan usaha industri pada variabel struktur aset (STA). Hal ini ditunjukkan dengan pertumbuhan basis aset dan pertumbuhan struktur permodalan. Hal ini sejalan dengan hipotesis prinsip Trade Off. Hasil temuan investigasi variebel profitabilitas dikatakan memiliki nilai koefisien 0,378 dan tingkat signifikansi 0,335 > 0,05 untuk perhitungan regresi berganda. Variabel profitabilitas tidak memiliki pengaruh apapun terhadap komposisi modal perusahaan. Karena dummy memiliki koefisien positif 71,432 dengan tingkat yang relevan 0,0075>0,05 maka dapat disimpulkan dari hasil investigasi yang dilakukan bahwa beberapa regresi dihitung. Dengan demikian variabel likuiditas tidak berpengaruh terhadap struktur permodalan perusahaan.

\section{KESIMPULAN}

Berdasarkan hasil penelitian diketahyui bahwa struktur aktiva memeiliki pengaruh positif terhadap struktur modal, artinya semakin maksimal struktur aset maka semakin maksimal juga struktur modalnya. Sementara variabel profitabilitas serta likuiditas, berdasarkan hasil penelitian tidak memiliki pengaruh terhadap struktur modal perusahaan.

\section{DAFTAR PUSTAKA}

Aprianto, F., Yunita, I., \& Iradianty, A. (2017). Analisis Kointegrasi Bursa Saham Indonesia dengan Bursa-bursa Saham di ASEAN. Almana: Jurnal Manajemen dan Bisnis, 1(1), 114-123.

Arsyad, N. (2015). Integration between East and Southeast Asian equity markets. Journal of Financial Economic Policy.

Christa, R., \& Pratomo, W. A. (2013). Analisis Pengaruh Indeks Harga Saham di Bursa Global terhadap Indeks Harga Saham Gabungan di BEI. Jurnal Ekonomi dan Keuangan, 1(8), 14757.

Kosasih. (2019). Creating Competitive Advantages for Companies by Developing Strategic Human Resource Management in the Face of the Challenges of the Revolution 4.0. International Journal of Science and Society, 1(4), 103-112.

Kustina, L., Anwar, S., \& Mawar, I. (2018). Pengaruh Bursa Saham Global Terhadap Indeks Harga Saham Gabungan Di Bursa Efek Indonesia. Jurnal Investasi, 4(1), 1-10.

Mawaddah, T., \& Nurwulandari, A. (2019). Pengaruh Indeks Klci, Sti, Set, Dan Psei (Integrasi Afta) Terhadap IHSG. Oikonomia: Jurnal Manajemen, 14(2).

Melati, M., \& Nurwulandari, A. (2019). Analisis Reaksi Pasar terhadap Stock Split pada Perusahaan Bertumbuh dan Tidak Bertumbuh. Oikonomia: Jurnal Manajemen, 13(2). 
Mitroglou, G. (2019). The Problem of Fair Management in Politics: Religious Argument and Personal Interest Argument. Endless, 2(1).

Noer, M., Saribanon, N., \& Nurwulandari, A. (2017). Business Model Analysis of Natural Production Forest with Sustainable Forest Management Approach. GeografiaMalaysian Journal of Society and Space, 13(1).

Nur, M., Effendy, K., Djaenuri, M. A., \& Lukman, S. (2019). Pengaruh Implementasi Kebijakan Pengawasan, Kompetensi Aparatur Dan Budaya Organisasi Terhadap Kinerja Pengawasan Bidang Pendidikan Dasar Di Kota Depok. Papatung: Jurnal Ilmu Administrasi Publik, Pemerintahan Dan Politik, 2(3), 107-117.

Rahim, M. A. A., Zahari, S. M., \& Shariff, S. S. R. (2016). Impact of univariate error distribution assumption toward multivariate GARCH parameter estimation performance. Int. J. Advance Soft Compu. Appl, 8(1).

Robiyanto, R. (2017). The Analysis of capital market integration in ASEAN Region by using the OGARCH approach. Jurnal Keuangan dan Perbankan, 21(2), 169-175.

Soedarmono, W. (2018). Stock market integration in the Asia-Pacific region: Evidence from cointegration of liquidity risk. Economics Bulletin, 38(1), 60-70.

Subhi, C. P., \& Fitriyah, F. (2014). Analisis Integrasi Pasar Modal Kawasan Asia-Pasifik (Apec): Implikasi Diversifikasi International. Iqtishoduna, 10(2), 99-109.

Suharsono, A., \& Wibisono, A. (2016). Pemodelan Harga Saham BLUE CHIP Menggunakan Vector Autoregressive (VAR). PERFORMANCE: Jurnal Bisnis \& Akuntansi, 6(2), 110.

Suparmun, H. (2012). Keterkaitan Dinamis Pasar Saham Indonesia dan Asia Pasifik. Jurnal Keuangan dan Perbankan, 16(1).

Zuhri, M., \& Endri, E. (2017). Analisis Keterkaitan Dinamis Pasar Saham di antara NegaraNegara ASEAN-5. Jurnal Keuangan dan Perbankan, 10(1). 